
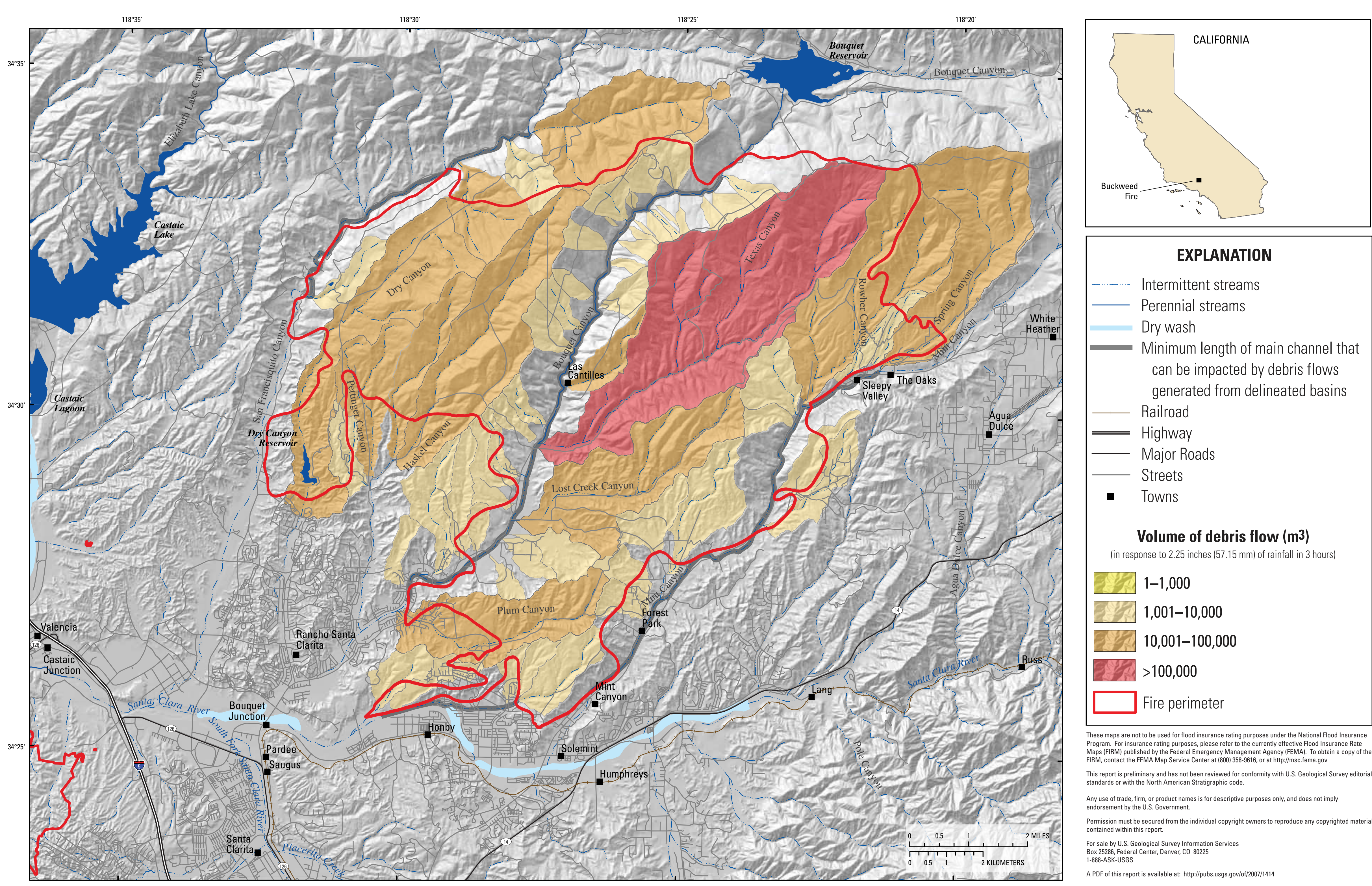

\title{
EXPLANATION
}

\section{-........ Intermittent stream}

_ Perennial streams

Dry wash

Minimum length of main channel that can be impacted by debris flows generated from delineated basins Railroad

- Highway

— Major Roads

- Streets

Volume of debris flow $\left(\mathrm{m}^{3}\right)$

\section{E1-1,000}

$1,001-10,000$

10,001-100,000

$>100,000$

\section{$\square$ Fire perimeter}

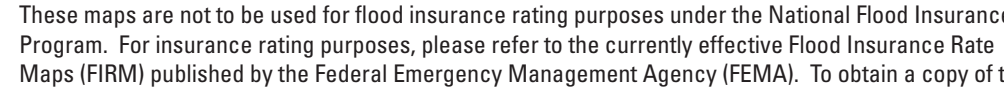

ireliminary and has not been reviewed for

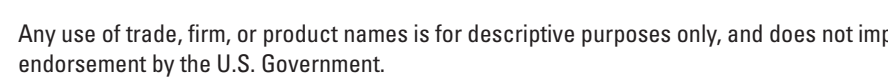

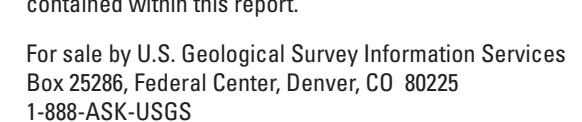

EMERGENCY ASSESSMENT OF DEBRIS-FLOW HAZARDS FROM BASINS BURNED BY THE 2007 BUCKWEED FIRE, LOS ANGELES COUNTY, SOUTHERN CALIFORNIA By Susan H. Cannon, Joseph E. Gartner, John A. Michael, Mark A. Bauer, Susan C. Stitt, Donna L. Knifong, Bernard J. McNamara, and Yvonne M. Roque 'U.S. Geological Survey, Box 25046, DFC, MS 966, Denver C0 80225, (303) 273-8604, cannon@usgs.gov

Introduction

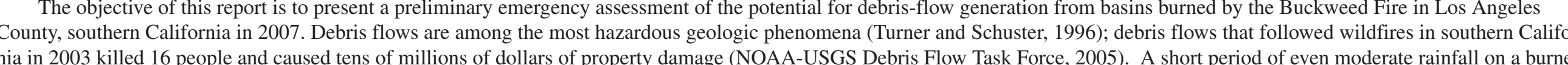
nia in 2003 killed 16 people and caused tens of millions of dollars of property damage (NOAA-USGS Debris Flow Task FFrce, 2005 ). A short period of even moderate rainfall on a burned
watershed can lead to debris flows (Cannon and others, 2008). Rainfall that is normally absorbed into hillslope soils can run off almost instantly after vegetation has been removed by

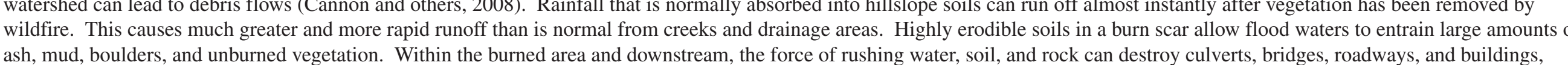
potentially causing injury or death

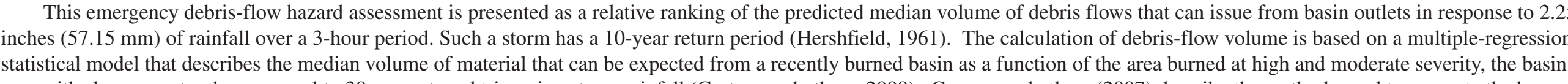

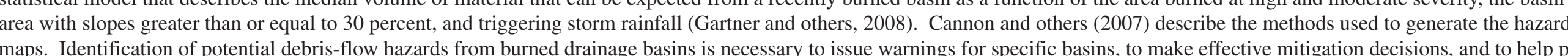

Results

All of the 64 basins evaluated in this assessment were identified as having the potential to produce debris flows with median volumes greater than 1,000 $\mathrm{m}^{3}$ in response to the 10-yed
Iecurrence, 3 -hour rainsto Pettinger, Haskel, Plum, Lost Creek, and Spring Canyons, and unnamed canyons west of Texas Canyon, between Pettinger and Haskel Canyons, north of Dry Canyon, and north of Haske Canyon could produce debris fllows with volumes between 10,001 and $100,000 \mathrm{~m}^{3}$. Volumes between 1,001 to $10,000 \mathrm{~m}^{3}$ are estimated for the remaining basins.
In addition to buildings, or people within any of the burned basins, debris flows issuing from burned canyons can impact streets and neighborhoods located near the fire. Travelers on
San Francisquito Canyon Road, the road that travels sp Bouguet Canyon, and any other road in the burned area can also be impacted.

\section{Use and Limitations of the Map}

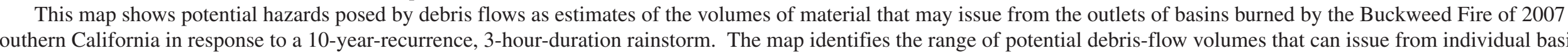

outtets. This information can be used to issue warning for specific locations, to prioritize mitigation efforts, to aid in the design of mitigation structures, and to guide decisions for evaciu-

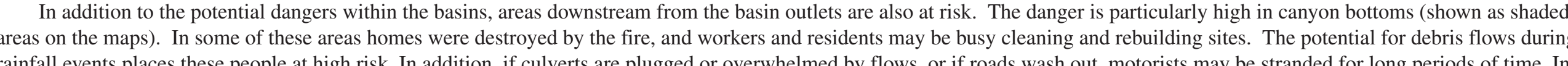
some cases, channels cross roads on blind curves where motorists could abruptly encounter debris-flow deposits on the road. In addition to the colored drainage basins, small debris flows can be generated from non-colored areas within the burn perimeter. These areas were not included in the analysis
because the are occupied by either hillslopes or basins that are smaller than those used in the model development (Cannon and others, 2007).

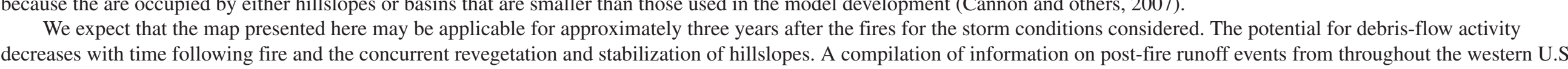

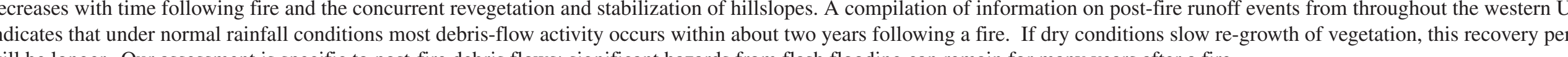

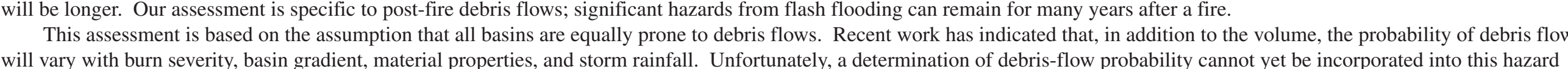

\section{Suggested Actions}

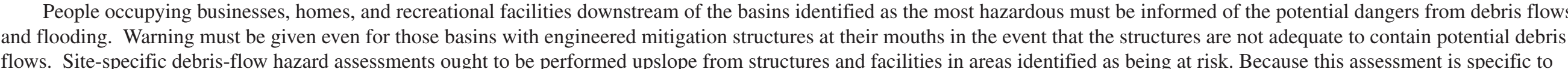
post-ire debris flows, ,

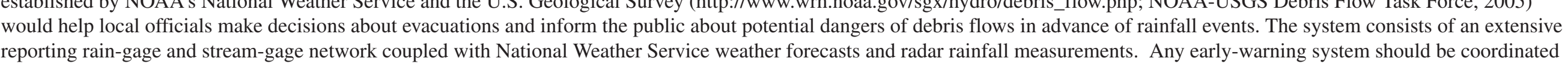
reporting rain-gage and stream-gage network coupled with National Weather Service weather forecasts and radar rainfall measurements. Any early-warning system should be coordinated
with existing county and flood dissict frilities An evaluation of the effectiveness of hillslope and channel mitigation approaches focused on the ability of different treatment methods to decrease the potential volume of debris flows
(deWolfe, 2006; deWolfe and others, 2008). This work found that extensive applications of treatments that rromote rainfall infiltration into hillslopes combinined with engineered works that control incision in low-gradient channel reaches can effectively mitigate debris-fllow impacts in basins less than about two km in in area that are expected to produce debris-fllow volumes of

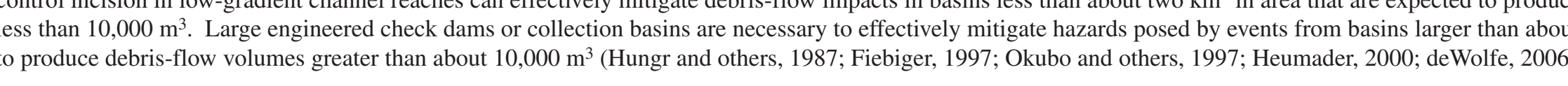

\section{References Cited}

Cannon, S.H., Gatner, J.E., and Michael, J.A., 2007, Me
Geological Survey Open-File Report 2007-1384, $10 \mathrm{p}$,

Cannon, S.H., Gartner, J.E., Wilson, R.C., and Laber, J.L., 2008, Storm rainfall conditions for floods and debris flows from recently burned areas in southwestern Colorado and southern
California: Geomorphology, doi:10.10191. geomorph.2008.03.019.

deWolfe, V.G., 2006, An evaluation of erosion control methods after wildfire in debrisis-flow prone areas after wildfire: Golden, Colorado School of Mines, Department of Geology and
Engineering Geology. MS thesis, 186 P

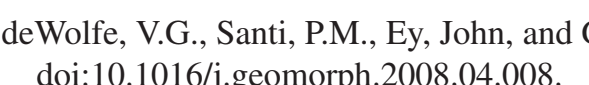

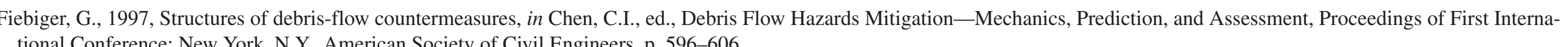

Hershifield, D.M., 1961, Rainfall frequency atlas of
Department of Commerce, weather Bureau, 61 p.

Heumader, J, 2000, Technical debris flow countermeasures in Austria-A review, in Wieczorek, G.F., and Naeser, N.D., eds., Debris flow Hazards Mitigation-Mechanics, Prediction,
and Assessment, Proceedings of Second International Conference on Debris Flow Hazards Mitigation: Taipei, Taiwan August 16-18, 2000, A.A. Balkema, Brookfield, Vt., p. 553-564 Hungr, Oldrich, Morgan, G.C., VanDine, D.F., and Lister, D.R.,., 1987, Debris flow defenses in British Columbia, in Costa, J.E., and Wieczorek, G.F., eds., Debris Flows Avalanches-

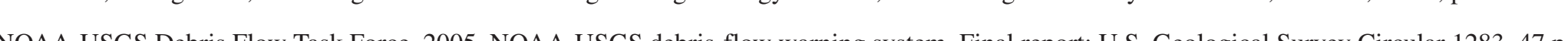

Okubo, S., Ikeya, H., Ishikawa, Y., and Yamada, T., 1997, Development of new methods for countermeasures agains
ments on Debris Flows, Lecture Notes in Earth Sciences, vol, 64, Springer-Verlag, New York, N.Y., p. $166-185$. 